\author{
dr Stanisław EJDYS \\ Wydział Społeczno-Ekonomiczny, Państwowa Wyższa Szkoła Zawodowa w Koninie \\ e-mail: ejdys.stanislaw@gmail.com
}

DOI: $10.15290 /$ ose.2017.04.88.15

\title{
SPÓJNY I ZRÓWNOWAŻONY SYSTEM TRANSPORTOWY WARMII I MAZUR
}

\begin{abstract}
Streszczenie
Dynamiczny rozwój transportu, mający miejsce w XX wieku, znacznie przyczynił się do większego zużycia surowców naturalnych, degradacji środowiska, a tym samym do zmniejszenia dobrobytu obecnych i przyszłych pokoleń. Zagadnienia te są tym bardziej złożone, że obecna sytuacja polityczna w Europie zmienia się szybciej niż warunki gospodarcze. Należy zaakceptować fakt, że wskutek problemów w polityce i gospodarce Unii Europejskiej, proces akceptacji założeń nowej polityki spójności może zostać wydłużony, a planowane priorytety moga zmienić pozycję w hierarchii. Tak więc, przyszłość zrównoważonego transportu zależy od tego, jakie działania obecnie zostaną podjęte.

Celem artykułu jest próba przedstawienia problematyki dotyczącej zrównoważonego transportu w aspekcie europejskiej polityki spójności. Rozważania nie wyczerpuja poruszanej problematyki. Wskazuja jedynie na wielowymiarowość i wieloaspektowość rozpatrywanego zagadnienia, stanowiąc przyczynek do dalszych badań w tym zakresie.
\end{abstract}

Słowa kluczowe: transport zrównoważony, system transportowy, polityka transportowa

\section{INTEGRATED AND SUSTAINABLE TRANSPORT SYSTEM OF WARMIA AND MAZURY}

\section{Summary}

The rapid development of transport which took place in the 20th century vastly contributed to greater consumption of raw materials, environmental decay, and hence to reducing the prosperity of present and future generations. These issues are all the more complex that the current political situation in Europe is changing more rapidly than the economic conditions. We must accept the fact that, as a result of the current problems of the European Union, the process of approval of the assumptions of the new cohesion policy can be lengthy and the planned priorities can change position in the hierarchy. Thus, the future of sustainable transport depends on what actions we will take now.

The purpose of this paper is to present the issues concerning sustainable transport against the background of European cohesion policy. The discussion is by no means comprehensive as it only indicates the multidimensional and multifaceted nature of the considered problems, suggesting areas for further research.

Key words: sustainable transport, transport system, transport policy

JEL classification: R42 


\section{Wstęp}

System transportowy ${ }^{1}$ Warmii i Mazur w sensie przestrzennym jest elementem krajowego i dalej międzynarodowego systemu transportowego. Jego rola jest tworzenie spójności społecznej i gospodarczej regionu dzięki zapewnieniu satysfakcjonującej dostępności komunikacyjnej przez wszystkich interesariuszy transportu. Powszechnie uważa się, że poprawa dostępności i spójności regionu w układzie drogowym dotyczy szerokiego pakietu działań mających na celu skrócenie czasu dojazdu do najważniejszych ośrodków w układzie krajowym i regionalnym. Wiąże się to z realizacją działań usprawniających ważne dla województwa połączenia drogowe, wiążące regionalny system transportowy z siecią dróg krajowych przebiegająca przez obszar województwa.

Ocena aktualnego stanu spójności przestrzennej Warmii i Mazur wskazuje, że region wciąż należy do obszarów o najmniejszej dostępności komunikacyjnej w Europie. Wschodnia część regionu to obszary o ekstremalnie niskiej dostępności. Zgodnie z Krajowa Strategia Rozpoju Regionalnego [2010], czas dojazdu samochodem do stolicy regionu znacząco przekracza 90 minut. Ponadto, duża liczba gmin charakteryzuje się najdłuższym czasem dojazdu do Warszawy. Wynika to z faktu, że gęstość dróg utwardzonych w województwie warmińsko-mazurskim jest najniższa w Polsce. Niezadowalający stan podstawowej infrastruktury drogowej nadal stanowi najistotniejszą barierę rozwoju regionalnej gospodarki, upośledzając jej konkurencyjność oraz negatywnie wpływając na warunki życia ludności.

Wobec powyższych przesłanek pojawia się pytanie o potencjalne źródła wzrostu gospodarczego regionu Warmii i Mazur w przyszłości i poprawy jego pozycji konkurencyjnej na tle innych województw. Powołując się na ekspertyzę dotyczącą województwa warmińsko-mazurskiego w kontekście Strategii rozumoju społeczno-gospodarczego Polski Wschodniej [2013] i na Strategie rozwoju społeczno-gospodarczego województwa warmińsko-mazurskiego do roku 2025 [2013] można stwierdzić, że efekty dotychczasowych działań nie są zadowalające. Przyczyn tego jest wiele, począwszy od niskiej skuteczności stosowanych instrumentów i konfliktów interesów przy realizacji inwestycji o znaczeniu międzynarodowym, przez nie zawsze trafne prognozy, po stałe rozszerzanie Unii Europejskiej oraz nowe realia gospodarcze stwarzające kolejne wyzwania i problemy. Ponadto, problem pogłębiają niekorzystne warunki naturalne do rozwoju infrastruktury transportu lądowego, takie jak ukształtowanie terenu czy też duży udział lasów i wód powierzchniowych.

Powyższe stwierdzenia świadczą o tym, że właściwa identyfikacja problemów, określenie ich hierarchii i wzajemnych współzależności pozwala na zdefiniowanie relacji przyczynowo-skutkowych. To z kolei stanowi podstawę do realizacji działań, które w konsekwencji są ukierunkowane na realizację celu, jakim jest sprawne i efektywne funkcjonowanie systemu transportowego [Ejdys, 2015, s. 314-327]. Kluczowe znaczenie

Termin system wydaje się jednym z wielu bardzo szeroko ujmowanych, a przez to często niejasnych fenomenów w rozwoju nie tylko nauk ekonomicznych. Różne dziedziny wiedzy próbują, każda ze swojej perspektywy, odnaleźć adekwatny do nich dostęp związany z tym obiektem, który od dawna i dla wielu jest pozornie łatwy do uświadomienia, lecz w istocie dotychczas długo wydawał się jakby obcy próbom precyzyjnego zdefiniowania jego treści. 
ma tu wdrożenie regionalnego systemu transportowego w liczne uwarunkowania określone przez układ: regionalny, krajowy i międzynarodowy ulegający ciąłym przemianom, wśród których najczęściej wymienia się:

- $\quad$ uwarunkowania przyrodnicze, związane z oddziaływaniem transportu na środowisko;

- $\quad$ uwarunkowania społeczne, wynikające $z$ faktu, że region jest złożonym systemem społecznym;

- uwarunkowania gospodarcze, związane z sytuacja gospodarczą zarówno regionu, jak i państwa;

- $\quad$ uwarunkowania przestrzenne, związane z będącą do dyspozycji przestrzenia, która stanowi dobro publiczne;

- uwarunkowania infrastrukturalne, związane z występującą na danym terenie infrastruktura.

Wyróżnione grupy uwarunkowań są niezależne, niekonkurencyjne i niewykluczalne. Trzeba je wszystkie uwzględniać, możliwie bez hierarchizacji lub wyróżnień. Wymagaja one pełnej enumeracji i charakterystyki ze wskazaniem rangowym wpływu na rozwój transportu. Można bowiem skonstatować, że są one z jednej strony następstwem istniejącego stanu systemu transportowego, a z drugiej wypadkową nadrzędnego celu, jakim jest jego rozwój [Grzywacz, Wojewódzka-Król, Rydzkowski, 2000, s. 20].

W obliczu powyższych przesłanek zasadniczym celem opracowania jest zwrócenie uwagi na konieczność zmian w podejściu do systemów transportowych oraz sposobów analizowania i diagnozowania występujących w nich problemów i to niezależnie od tego, czy chodzi o poziom lokalny, regionalny, krajowy czy też międzynarodowy. Natomiast przesłanek podjęcia tematu należy doszukiwać się w fakcie, że współczesna gospodarka podlega nieustannej ewolucji. Tym samym system transportowy, stanowiący jeden z filarów jej rozwoju, nie jest wolny od zmian. Ważne jest, aby konieczność tych zmian została dostrzeżona we właściwym czasie i poddana właściwej analizie, której rezultatem będzie zmodyfikowane podejście do definiowania i programowania systemów transportowych. Trudno bowiem spodziewać się stagnacji i opierać się na tradycjonalistycznym podejściu do systemów transportowych w sytuacji globalizacji gospodarki i braku zrównoważenia transportu oraz innych ważnych, globalnych trendów cywilizacyjnych.

\section{Charakterystyka systemu transportowego Warmii i Mazur}

Stan transportu w każdym regionie najlepiej odzwierciedla charakterystyka jego systemu transportowego, który, najogólniej ujmując, składa się z sieci infrastruktury transportowej oraz jej użytkowników, tj. przewoźników o określonym potencjale przewozowym zdolnym do przemieszczania towarów i osób. Uprawnione jest więc twierdzenie, że system transportowy to całokształt środków technicznych i ludzkich zatrudnionych w celu świadczenia usług transportowych [Liberadzki, 1998, s. 98]. Zaprezentowana definicja zwraca uwage na istotne kwestie z racji tematyki niniejszego artykułu, a mianowicie, podkreśla fakt doboru różnych zasobów do realizacji określonego celu, 
jakim jest sprawne przemieszczanie osób i ładunków w czasie i przestrzeni. Jednocześnie takie ujęcie problemu pozwala na stosowną interpretację w aspekcie: funkcjonalnym, przedmiotowym i ocenowym ${ }^{2}$.

Takie ujęcie problemu pozwala zarazem określić region Warmii i Mazur mianem podwójnej peryferii [Proniewski, 2012, s. 63-74], albowiem jest położony peryferyjnie w peryferyjnym kraju. Zewnętrzna granica Polski, przy której leży, jest zarazem wschodnią granicą Unii Europejskiej. Poza tym, peryferyjność regionu ma nie tylko wymiar przestrzenny - definiowany odległością od centrów rozwojowych Polski i Unii Europejskiej - jest on peryferia w sensie społeczno-gospodarczym ${ }^{3}$. Powszechnie przyjmuje się, że rozwój gospodarczy Warmii i Mazur należy do najniższych we Wspólnocie.

Region Warmii i Mazur, ze względu na swoje specyficzne położenie, dysponuje różnymi rodzajami transportu: od drogowego, poprzez kolejowy, lotniczy, żeglugę śródlądowa, na żegludze morskiej kończąc. W pobliżu zachodniej części województwa przebiega autostrada A1, przez jego zachodnie obszary droga ekspresowa nr 7, zaś w północnej części przebiega droga ekspresowa nr 22. W sąsiedztwie województwa warmińsko-mazurskiego znajdują się duże porty morskie w Gdańsku i Kaliningradzie, a potencjał komunikacyjny uzupełnia międzynarodowa droga wodna E70.

Obecnie na wielu odcinkach dróg szczególnie ważne są takie drogi, jak: ekspresowa numer $7 \mathrm{i}$ krajowa numer 16 oraz są realizowane liczne projekty modernizacyjne. Ze względu na rozwój sieci transportowej istotne jest to, że wymienione wcześniej połączenia drogowe, a także Via Baltica - przebiegająca przez Ełk w kierunku Warszawy - oraz linie kolejowe: Ełk - Korsze - Olsztyn - Iława i Rail Baltica należą do sieci TEN-T (Transeuropejskie Sieci Transportowe), których realizacja jest priorytetowa dla Unii Europejskiej, jak również rządu Polski. W okresie programowania 2014-2020 środki Unii Europejskiej mają być w znacznie większym stopniu koncentrowane właśnie na rozwoju transeuropejskich sieci (TEN), w tym transportowych (TEN-T).

Niestety, Warmia i Mazury wciąż kwalifikują się do obszarów o najmniejszej dostępności komunikacyjnej w Europie. Największe problemy i słabości województwa w poszczególnych rodzajach transportu można scharakteryzować następująco:

- $\quad$ transport drogowy, gęstość dróg o twardej nawierzchni jest w województwie najniższa w całym kraju $\left(53,3 \mathrm{~km} / 100 \mathrm{~km}^{2}\right)$, co należy wiązać z: niska gęstością zaludnienia, rozproszoną siecią osadniczą oraz niskim poziomem rozwoju społeczno-gospodarczego regionu. Niezależnie od przyczyn, województwo warmińsko-mazurskie wyróżnia się dużą liczba gmin, które należą do grupy tych jednostek w Polsce, w których najdłuższy jest czas dojazdu do miasta powiatowego oraz czas dojazdu do Warszawy;

- $\quad$ transport kolejowy, gęstość linii kolejowych w województwie warmińsko-mazurskim należy do najniższych w Polsce $\left(5 \mathrm{~km} / 100 \mathrm{~km}^{2} ; 13\right.$. miejsce w kraju).

2 W świetle przyjętej definicji transport regionalny jest postrzegany jako system dynamiczny, złożony i wielki, o dużym stopniu spójności i ograniczonej zdolności do samoregulacji, podlegający transformacji, który w dalszej części artykułu będzie przedmiotem rozważań.

3 Po rozszerzeniu Unii Europejskiej w 2007 roku o Bułgarię i Rumunię, czyli regiony słabiej rozwinięte, województwa Polski Wschodniej, w tym Warmia i Mazury, nadal znajdowały się wśród najbiedniejszych regionów Unii Europejskiej. 
W dużej części stan techniczny eksploatowanych linii kolejowych jest średni lub zły ${ }^{4}$, a ponadto odnotowuje się wciąż spadek długości linii eksploatowanych, w 2012 roku z $1509 \mathrm{~km}$ do 1 238;

- transport lotniczy, lotnisko w Szymanach koło Szczytna jest lotniskiem regionalnym z możliwością obsługi lotów międzynarodowych. Kolejne to lotniska lokalne, takie jak: Olsztyn-Dajtki, Elblagg i Kętrzyn, a poza tym dwa lądowiska: Gryźliny i Elblag. Lokalne samorządy planują również swoje lotniska w Ełku i Wilkowie koło Olsztynka;

- transport żegluga śródlądowa, na terenie województwa istnieje sześć dróg wodnych, przy czym jedna - System Wielkich Jezior Mazurskich - tworzy rozległa sieć powiązań, a do pozostałych dróg wodnych należą: Kanał Bartnicki, Kanał Elbląski, Kanał Jagielloński, Rzeka Nogat i Rzeka Pisa. Mają one znaczenie dla turystyki wodnej. Znaczenie dróg śródlądowych dla transportu ładunków jest niewielkie w przypadku Warmii i Mazur, w przeciwieństwie do transportu pasażerskiego;

- $\quad$ transport morski, na terenie województwa nad Zalewem Wiślanym funkcjonują cztery porty - Elbląg, Frombork, Nowa Pasłęka i Tolkmicko oraz cztery przystanie. Porty we Fromborku, Tolkmicku oraz po stronie pomorskiej, tj. w Krynicy Morskiej, pełnią funkcje portów pasażerskich, eksploatowanych głównie turystycznie. W 2010 roku do portu we Fromborku zawinęło 365 statków, a do Krynicy Morskiej 404, głównie w ramach rejsów między tymi właśnie portami. Funkcje transportowe pełni Port Morski w Elblagu - jako jedyny port morski towarowy w województwie. Pocieszający jest fakt, że po latach zastoju, od 2010 roku szybko odbudowuje on swoją pozycję w regionie pod względem wielkości przeładunków.

Cały układ transportowy uzupełniaja graniczne przejścia lądowe (pięć drogowych i dwa kolejowe), następnie morskie (Elblag i Frombork) oraz lotnicze (Szymany). Kilka nowych przejść jest proponowanych do realizacji, niemniej jednak nie zmieni to faktu, że przejścia graniczne moga być czynnikiem rozwojowym, gdy po obu stronach granicy będzie występował potencjał współpracy. Jak dotąd, współpraca z obwodem kaliningradzkim nie może być uznawana za bardzo istotny czynnik rozwojowy, choć pewne nadzieje można wiązać $z$ bezwizowym, małym ruchem przygranicznym.

W konkluzji należy uznać, że region Warmii i Mazur potrzebuje poprawy dostępności przestrzennej w zakresie ilościowego i jakościowego rozwoju infrastruktury transportowej. Dostępność przestrzenna ma kluczowe znaczenie dla rozwoju gospodarki $i$ to na wszystkich jej poziomach, od unijnego do lokalnego. Potwierdza to teza, iż żyjemy w świecie, w którym rządzi ruch i czas. Poza tym, rozwój transportu stanowi warunek przemian współczesnego świata. Przynosi on ludzkości zdolności poruszania się i transportu dóbr, rozszerza horyzonty rozwoju człowieka, daje mu możliwość zagospodarowania nowych obszarów oraz stwarza nowe przyzwyczajenia zarówno w zakresie życia codziennego, jak i pracy [Bahke, 1971, s. 236-237].

4 Zalecane jest wykonanie natychmiastowego remontu, ponieważ jego opóźnienie prowadzi do zupełnej degradacji odcinka i zwielokrotnienia kosztów remontu. 


\section{Polityka transportowa Unii Europejskiej w kształtowaniu systemów transportowych}

Akcesja Polski do Unii Europejskiej spowodowała konieczność przyjęcia całego dorobku prawnego Wspólnoty, między innymi dotyczy to regulacji rynku usług transportowych. Funkcjonowanie i rozwój transportu regionalnego w dużym stopniu zależą od wyboru polityki transportowej oraz od sposobu jej realizacji.

Polityka, jako sztuka rządzenia państwem, jest zajęciem bardzo trudnym i skomplikowanym, a tym bardziej polityka transportowa w obecnej rzeczywistości gospodarczej Polski, przed którą stoją ogromne wyzwania związane z wizją transportu XXI wieku, zarysowane w dokumentach Wspólnoty. W tym kontekście należałoby stwierdzić, iż polityka transportowa jest procesem dokonywania odpowiedniego wyboru przedsięwzięć z zakresu rozwoju i funkcjonowania transportu pod względem różnych kryteriów, np. ekologii czy mobilności, ale i procesów oddziaływania grup interesariuszy zainteresowanych określonymi rozwiązaniami. Jest to zatem gra, w której uczestniczy wielu graczy i których interesy mogą być wzajemnie sprzeczne. Dlatego też powinno się wspierać te inicjatywy, które sprzyjają budowaniu wspólnej wizji transportu obejmującej integrację rozwiązań transportowych [Ejdys, 2014, s. 29-43].

W związku z powyższym politykę transportową można zdefiniować jako programowanie rozwoju systemu transportowego oraz oddziaływanie na jego sprawne funkcjonowanie z uwzględnieniem wymagań teorii i praw ekonomicznych [Grzywacz, Wojewódzka-Król, Rydzkowski, 2000, s. 11]. W definicji tej założono aktywną rolę państwa, choć nie przesądzono jaki jest pożądany zakres regulacji rynku transportowego. Natomiast znaczące jest to, aby regulacje te, będące następstwem przyjętej polityki transportowej, służyły warunkom sprawnego i bezpiecznego, a także efektywnego ekonomicznie przemieszczania się ludzi. Tak więc, chodzi o sztukę, przez którą rozumie się umiejętność sprawnego rządzenia po to, by realizować wybrane cele. Jednak osiagnięcie zamierzonych celów wymaga zastosowania skutecznych środków oraz metod ich realizacji.

Polityka transportowa, jako forma regulacji systemu transportowego zgodnego $\mathrm{z}$ wizją podmiotu, który ją opracowuje i realizuje, z reguły przyjmuje charakter programowy [Grzelakowski, Matczak, Przybyłowski, 2008, s. 35]. Jest ona dokumentem stanowiącym zbiór: zasad, celów, priorytetów proponowanych działań i wskazań dotyczących: planowania, projektowania, realizacji i administrowania rozwojem transportu. Nie zastępuje dokumentów planistycznych w zakresie transportu, ale jest $\mathrm{z}$ nimi ściśle skorelowana. Ma za zadanie naświetlić kierunki rozwoju transportu tak, aby było możliwe osiagnięcie zrównoważonego pod względem: technicznym, przestrzennym, gospodarczym, społecznym i środowiskowym systemu transportowego zapewniającego powszechną dostępność do poszczególnych rejonów obszaru.

Cele polityki transportowej sa różnie konstruowane i ujmowane w dokumentach programowych. Najczęściej jest formułowany cel główny regulacji systemu transportowego w określonym czasie, który wskazuje kierunek rozwoju danego systemu, zgodny z priorytetami i założeniami, niekiedy tylko z pewną wizją podmiotu kształtującego politykę transportową miasta. Poza celem strategicznym mogą być formułowane cele 
operacyjne, zwykle podporządkowane celom strategicznym. Mają one wspólną myśl przewodnią, która zmierza do realizacji celu strategicznego, a także następujące zadania:

- $\quad$ uszczegółowić cel strategiczny, czyniąc go bardziej przejrzystym i czytelnym w aspekcie programowo-realizacyjnym;

- $\quad$ ułatwić realizację celu głównego dzięki wskazaniu możliwości jego adaptacji w rzeczywistości;

- $\quad$ uelastycznić procedury planistyczne i realizacyjne celu strategicznego przez dostosowanie ich do zmiennych i trudnych warunków otoczenia.

W tym kontekście polityka transportowa tworzy pewną strukturę celów, która musi być spójna pod względem: przedmiotowym, przestrzennym i czasowym, bowiem realizacja jednego subcelu warunkuje realizację kolejnego. Ważne jest przy tym, by cele przyjęte do realizacji były formułowane w kategoriach zgodnych z kryteriami $S M A R T$, takimi jak:

$S$ - specific - jednoznacznie zidentyfikowany, konkretny;

$M$ - measurable - mierzalny;

$A$ - actionable - dający się przełożyć na działania;

$\mathrm{R}$ - realistic - realny (osiagalny);

T-timetabled - posiadający swój horyzont czasowy.

Jednakże wiadomo, że zachowanie tych wymogów z różnych przyczyn w praktyce transportowej często jest trudne do spełnienia, co realnie obniża skuteczność działania tego mechanizmu regulacji oraz może rodzić sytuacje kolizyjne zarówno w ramach systemu transportowego, jak i w układzie relacji z jego otoczeniem. Mimo wszystko zawsze należy dążyć do takiej konstrukcji celów, aby odpowiadały one w jak najwyższym stopniu wyróżnionym wcześniej wymaganiom. Jest to bowiem wymóg efektywności i skuteczności działania polityki transportowej [Mendyk, 2009, s. 388-389].

Jednym z celów wspólnej polityki transportu Unii Europejskiej jest zwiększenie efektywności energetycznej oraz dopilnowanie, by do 2050 roku system transportu był systemem zrównoważonym. W związku z tym określono trzy ogólne cele, takie jak:

- rozwijanie i wdrażanie nowych i zgodnych z zasadą zrównoważonego rozwoju paliw oraz układów napędowych;

- optymalizowanie multimodalnych łańcuchów logistycznych, w tym przejście na bardziej energooszczędne środki transportu;

- $\quad$ zwiększanie efektywności przez stosowanie systemów informacyjnych i zachęt rynkowych.

Sposobem na realizację wyżej wymienionych celów jest ograniczanie dystansu podróży przy jednoczesnym utrzymywaniu lub zwiększaniu dostępności.

Jeżeli europejska polityka transportowa ma przynieść sukces, nie można ignorować aspektu miejskiego. Obszary zurbanizowane to ważne węzły europejskiego systemu transportu, a większość podróży rozpoczyna się lub kończy w miastach. Co więcej, wiele negatywnych skutków transportu (np. zagęszczenie ruchu i zanieczyszczenia) występuje przede wszystkim na obszarach miejskich. Jak wynika z badań, połowa Europejczyków codziennie korzysta z samochodu (50\%), co oznacza, że takich osób jest więcej 
niż podróżujących rowerem (12\%) i korzystających z transportu miejskiego (16\% łącznie). Z drugiej strony zdecydowana większość Europejczyków uważa, że poważnymi problemami w miastach są zanieczyszczenie powietrza $(81 \%)$, zagęszczenie ruchu $(76 \%)$, koszty podróżowania $(74 \%)$, wypadki $(73 \%)$ oraz wzmożony hałas $(72 \%)$ [http://www.europarl.europa.eu/sides/getDoc.do?pubRef=-//EP//TEXT+REPORT +A8-2015-0319+0+DOC+XML+V0//PL]. Dzięki pakietowi na rzecz mobilności w miastach, Komisja wzmacnia wsparcie dla transportu miejskiego na okres programowania 2014-2020. Planowanie mobilności w miastach ściśle jest związane z dążeniem do realizacji unijnych celów prowadzących do stworzenia konkurencyjnego i zasobooszczędnego systemu transportu w Europie, lecz organizacja mobilności w mieście to głównie obowiązek władz szczebla lokalnego. Przez wiele lat unijne inicjatywy w zakresie mobilności w miastach były ukierunkowane w stronę wspierania wysiłku podejmowanego na poziomie miast, który przejawiał się działaniami niosącymi wyraźną wartość dodaną dla Unii Europejskiej. W ramach obecnego pakietu państwa członkowskie zachęca się do:

- prowadzenia uważnej analizy obecnych i przyszłych wyników w zakresie mobilności w miastach w świetle kluczowych celów polityki Unii Europejskiej;

- dopilnowania, aby dochodziło do tworzenia i wdrażania zrównoważonych planów w zakresie mobilności w miastach;

- dokonywania przeglądu technicznych, opartych na polityce, prawnych, finansowych i innych narzędzi, jakie mają do dyspozycji organy odpowiedzialne za miejskie planowanie przestrzenne [S zósty raport na temat spójności gospodarczej, 2014].

Centralnym elementem pakietu jest Komunikat „Wspólne dążenie do osiagnięcia konkurencyjnej i zasobooszczędnej mobilności w miastach" wraz z załącznikiem, w którym omówiono koncepcję zrównoważonych planów na rzecz mobilności w miastach oraz cztery dokumenty robocze dotyczące kolejno: logistyki miejskiej, przepisów w sprawie dostępu do ruchu miejskiego, uruchamiania inteligentnych systemów transportowych i bezpieczeństwa ruchu drogowego.

\section{Integracja systemów transportowych w cieniu europejskiej polityki spójności}

Wielowymiarowa i wieloaspektowa integracja ${ }^{5}$ transportu stanowi zarówno przedmiot badań naukowych, jak i rozwiązań praktycznych. Stała się także podstawą polityki transportowej prowadzonej w skali Unii Europejskiej, poszczególnych państw członkowskich, regionów, a także miast. Co więcej, przyznano jej szczególne znaczenie w polityce transportowej. Odzwierciedla to fakt użycia sformułowania w tytule Komunikatu Komisji kończącego konsultacje społeczne nad założeniami europejskiej polityki trans-

5 Integracja jako pojęcie wieloznaczne - różnie także interpretowane - obejmuje działania związane z: łączeniem, składaniem, dopełnianiem, jednoczeniem, a także scalaniem kilku elementów w całość. Uogólniając, można stwierdzić, że integracja oznacza proces tworzenia się całości z części lub zespalanie elementów w całość. 
portowej na druga dekadę XXI wieku. Brzmi on: „Zrównoważona przyszłość transportu: w kierunku zintegrowanego, zaawansowanego technologicznie i przyjaznego użytkownikowi systemu" [http://eur-lex.europa.eu/legal-content/PL/TXT/ ?uri=CELEX\%3A52009AE1950].

Poruszony aspekt jest o tyle istotny, iż ukazuje system, w którym musi istnieć spójność, czyli określony poziom integracji. Oznacza to, że tak w teorii, jak i praktyce system transportowy nie może być zdezintegrowany, tzn. istnieć i funkcjonować bez powiązań czy też relacji pomiędzy takimi elementami, jak: drogi, węzły i środki przewozowe [Bąkowski, 2007, s. 35]. Skłania to do pogłębienia przedmiotowych problemów i pozwala twierdzić, że integracja transportu jest procesem długofalowym, wymagającym tworzenia jednolitej struktury: prawnej, organizacyjnej, technicznej i ekonomicznej tak, aby wyniki tego procesu przyniosły korzyści wszystkim integrującym się elementom. Natomiast dochodzenie do „całkowitej” integracji systemu transportowego powinno odbywać się stopniowo, w wyniku pokonywania kolejnych barier dezintegracyjnych. Tylko wówczas system ten zachowa wymaganą spójność w układzie wewnętrznym oraz w ramach swych rozlicznych relacji z otoczeniem.

Z powyższego wynika, że integracja transportu może być rozpatrywana na różnych płaszczyznach i w wielu aspektach, dlatego można mówić o rozmaitych jej formach i rodzajach. Przykładowo, tylko w zależności od rodzaju lub gałęzi transportu, można rozprawiać o integracji w zakresie przewozu osób lub ładunków czy też integracji transportu publicznego. Natomiast, w ujęciu geograficznym, można wskazać na integrację: lokalną, regionalną, krajową bądź międzynarodową.

Generalnie, procesy integracyjne w sektorze transportu przejawiają się łańcuchem sekwencyjnych działań, którego istota jest możliwość uzyskania dodatkowych korzyści. Jednak należy zwrócić uwagę na to, że nie zawsze i w każdych warunkach korzyści te wystąpia, ponieważ nie każdy proces łączenia elementów pozwala na uzyskanie efektu synergii i tym samym nie będzie prowadzić do powstania dodatkowych korzyści związanych z realizowanym celem. W tym kontekście można również dodać, że integracja, jak każdy proces w gospodarce, ma swoje optimum i cenę, a ściślej efektywność ekonomiczna, stąd tylko obserwacja połączona z pomiarem może dać oczekiwane uzasadnienia ustalania zakresu i obszarów jej przeprowadzania [Tomanek, 2010, s. 275].

Reasumując, integracja w transporcie może oznaczać korzyści dla wszystkich użytkowników, w tym i organizatora transportu, lecz są to także problemy, które należy rozwiązywać. Poczynając od problemów o charakterze formalnym i prawnym związanych z organizacją systemu transportowego w ramach spójnej sieci komunikacyjnej, a kończąc na dylematach o charakterze operacyjnym dotyczących funkcjonowania zintegrowanego transportu. W większości wynikają one z konieczności scalenia różnych systemów, które dotąd funkcjonowały niezależnie. Pozwala to mieć nadzieję, że w przyszłości spójny system transportowy zapewni mieszkańcom i podmiotom gospodarującym realizację szeregu potrzeb transportowych na wysokim poziomie i w efekcie przyczyni się do rozwoju oraz wzrostu konkurencyjności całego regionu. 


\section{W kierunku zrównoważonego transportu Warmii i Mazur}

Zrównoważony rozwój jest jednym z najważniejszych wyzwań współczesnego świata. Pojęcie to w sposób najbardziej przejrzysty i powszechnie stosowany zostało zdefiniowane przez Światową Komisję Brundtland, powstałą w 1983 roku. Precyzuje ona zrównoważony rozwój jako taki, w którym potrzeby obecnego pokolenia moga być zaspokajane bez pozbawiania możliwości zaspokojenia potrzeb przyszłych pokoleń. Stwierdzenie to, choć nie pretenduje do miana definicji zrównoważonego rozwoju, ponieważ nie precyzuje i nie wyjaśnia szczegółowo pojęcia, ma trzy podstawowe zalety. Po pierwsze, daje pozytywny przekaz społeczności na temat możliwości rozwojowych gospodarki światowej. Po drugie, ma niezaprzeczalny walor ponadczasowości w określaniu wszelkich zjawisk ekonomicznych, a po trzecie, jest zarówno proste, jak i intuicyjnie łatwe do zaakceptowania [Bocian, 2009, s. 149].

W świetle powyższych wywodów nie ma wattpliwości co do tego, że rozwój systemu transportowego jest procesem ciagłym. Nie istnieje stan docelowy, do którego by on dążył. Każdy osiagnięty stan jest stanem przejściowym, który stanowi podstawę następnego etapu rozwoju. Tak rozumiany rozwój umożliwia osiaganie lepszych warunków funkcjonowania dzięki dokonywaniu pozytywnych zmian.

Z pewnościa proces rozwoju systemu transportu zrównoważonego musi być działalnością: świadoma, celową i prospektywna, prowadzoną w interesie lokalnych społeczności. Tylko wtedy, przynajmniej z czysto teoretycznego punktu widzenia, zostaną stworzone warunki rozwoju zrównoważonego, tj. takiego, który przyniesie maksymalne efekty ogólnospołeczne satysfakcjonujące uczestników tego rozwoju, odpowiednie i oczekiwane efekty indywidualne oraz będzie przebiegać przy minimalnym ryzyku niepowodzenia [Parysek, 2001, s. 123]. Stąd też realizacja interesu ogólnospołecznego i indywidualnego za przyczyną wykorzystania lokalnych i regionalnych czynników rozwoju sprawia, że proces ten powinien być sterowany i modyfikowany przez struktury samorządowe lub inne struktury organizacyjne, reprezentujące lokalne społeczności. Ponadto, jako przedsięwzięcie obciążone pewnym ryzkiem wymaga stałej kontroli i oceny jego realizacji i przebiegu.

Powyższe przesłanki wskazują, że jednym z głównych celów każdego regionu powinno być stwarzanie warunków do sprawnego i bezpiecznego, a zarazem efektywnego przemieszczania osób i ładunków, przy jednoczesnym ograniczaniu szkodliwego wpływu na środowisko naturalne.

W tym kontekście przyjęcie podejścia zrównoważonego w odniesieniu do systemu transportowego Warmii i Mazur wydaje się być właściwe i zadowalające (rysunek 1.). Świadczą o tym opinie środowiska naukowego oraz działania lokalnych społeczności, zrzeszonych w różnego rodzaju stowarzyszeniach promujących ideę zrównoważonego rozwoju. Brakuje jedynie konkretnych, często drastycznych i niepopularnych politycznie działań, które rzeczywiście mogłyby przyczynić się do równoczesnej poprawy jakości życia mieszkańców i środowiska naturalnego. Bez tego, system zrównoważonego transportu może okazać się jedynie fikcją. 


\section{Zrównoważone rozwiązania w transporcie}

\section{RYSUNEK 1.}

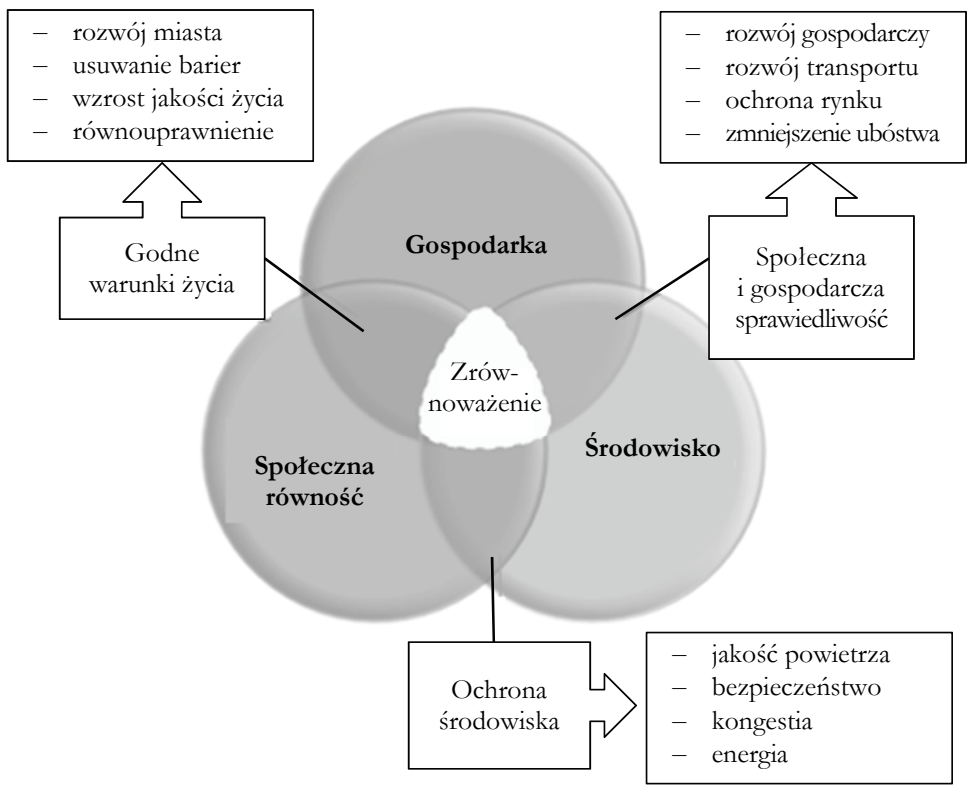

Źródło: opracowanie własne na podstawie: [Urban Mobility in Developing Countries, 2007].

Oczywiste jest to, że rozwój systemu transportowego powinien odbywać się w sposób uporządkowany na podstawie mozaiki planów o różnej skali przestrzennej i różnym horyzoncie czasowym. Natomiast wizja ${ }^{6}$ przyszłego transportu zrównoważonego powinna przedstawiać pożądany dla regionu i lokalnych społeczności jego kształt i cechy, różniący się od jego obecnego stanu pod względem dużych zespołów wdrożonych rozwiązań innowacyjnych [Burnewicz, 2008, s. 24].

Naturalnie, wizja to nie prognoza ani plan czy też program, a jedynie wyjściowe idee związane z jego stworzeniem. Jest to spojrzenie na przyszłość transportu przez pryzmat innowacyjnych tendencji na świecie, które moga być do niego transferowane. Stąd też na gruncie ściśle teoretycznym można sobie wyobrazić, że jest to wizja optymistyczna, ukazująca zrównoważony system transportowy Warmii i Mazur jako:

- $\quad$ sprawny, tak aby był w stanie obsłużyć masowe potoki ładunkowo-pasażerskie na jak najwyższym poziomie;

6 Wizja to sposób widzenia i wyobrażenia, który oznacza: szeroką koncepcję, pożądany obraz przyszłości, organizacji i jej miejsca w otoczeniu, wyrażanie intencji i aspiracji, bez szczegółowego określenia sposobów i środków osiągania celów. Wizja przyszłości ze swej istoty musi zawierać pierwiastki innowacyjne oraz określać różnice między starym a nowym stanem rzeczy. 
- $\quad$ elastyczny, tak aby lokalne społeczności miały możliwość przemieszczania się zgodnie ze swoimi preferencjami i oczekiwaniami, z wykorzystaniem różnych form i środków transportu;

- efektywny, zwłaszcza w zakresie eksploatacji, tak aby finansowanie bieżącego utrzymania transportu nie ograniczało aktywności inwestycyjnej w zakresie nowych technologii i jego rozwoju;

- zintegrowany nie tylko $\mathrm{w}$ ramach samego regionalnego systemu transportu, ale także $z$ transportem miejskim i ponadregionalnym;

- $\quad$ nowoczesny i ekologiczny, tak aby przyciagał rzesze interesariuszy oraz był pozytywnym elementem wizerunku Warmii i Mazur, jak również zapewniał zrównoważony rozwój regionu [http://hdl.handle.net/11320/2781].

W tym kontekście osobnym problemem pozostaje bezpieczeństwo związane zarówno z ruchem pojazdów, jak i poprawą bezpieczeństwa ładunków, a także osób przebywających w środkach transportu. Jednak poprawę bezpieczeństwa oczekuje się uzyskać dzięki działaniom obejmującym poszczególne cele, stąd też autor nie określił osobnego priorytetu dotyczącego bezpieczeństwa w transporcie.

Należy podkreślić, że zarysowana koncepcja modelu transportu Warmii i Mazur uwzględnia najważniejsze elementy koncepcji zrównoważonego rozwoju. Wzmacnia korzyści i ogranicza koszty transportu, w tym jego koszty zewnętrzne. Jest sformułowana na miarę/w równej mierze obecnych jak i przyszłych potrzeb mieszkańców regionu. Nie jest więc żadną utopią twierdzenie, że Warmia i Mazury mogą dysponować systemem transportu zrównoważonego, który w sposób zintegrowany przestrzennie i zrównoważony przyrodniczo pozwoli sprawnie realizować procesy przemieszczania ludzi i towarów. Wystarczy, że zostaną wyeliminowane dotychczasowe subiektywne bariery i uprzedzenia wszystkich jego interesariuszy.

\section{Podsumowanie}

Nie ulega wątpliwości, że podjęte w pracy zagadnienia zrównoważonego rozwoju i funkcjonowania systemu transportowego Warmii i Mazur wywołują żywe, społeczne i polityczne zainteresowania mieszkańców regionu. W głównej mierze wiąże się to z: wpływem funkcjonowania transportu na jakość życia, korelacja jego rozwoju z rozwojem gospodarczym regionu oraz silnym oddziaływaniem transportu na środowisko przyrodnicze. Dziś już wiadomo, że spójny i nowoczesny system transportowy jest niezbędnym komponentem konkurencyjnego regionu. Łączy obszar w układzie funkcjonalnym i przedstawia region jako system współzależności zachodzących między jego elementami.

Rozważania przeprowadzone $\mathrm{w}$ artykule uwidaczniają skalę problemów i trudności, z jakimi boryka się system transportowy Warmii i Mazur. Dowodzą i utwierdzają autora w przekonaniu o słuszności przyjęcia hipotezy, iż funkcjonowanie oraz rozwój zrównoważonego i zintegrowanego systemu transportowego Warmii i Mazur jest rezultatem szeregu uwarunkowań wynikających z: sytuacji społeczno-gospodarczej regionu, 
determinacji we wprowadzaniu zasad gospodarki rynkowej, a także wspólnej polityki transportowej.

\section{Literatura}

Bahke E., 1971, Systemy transportowe dzisi i jutro, Wydawnictwo Komunikacji i Łączności, Warszawa.

Bakkowski W., 2007, Procesy integracyjne w systemie transportowym a generowanie wartości dodanej, [w:] Procesy integracyjne wybranych systemów transportowych, M. Michałowska (red.), Prace Naukowe Akademii Ekonomicznej w Katowicach, Wydawnictwo Akademii Ekonomicznej w Katowicach, Katowice.

Bocian A., 2009, Implementacja idei zrównoważonego rozwoju w procesie globalizacji, [w:] Zrównoważony rozwój gospodarki opartej na wiedzy, B. Poskrobko (red.), Wydawnictwo Wyższej Szkoły Ekonomicznej w Białymstoku, Białystok.

Ejdys S., 2014, Polityka transportowa miasta - cele i wyzwania, [w:] Uwarunkowania i czynniki w procesie rozwoju gospodarki rynkowej. Aspekty globalne i lokalne, W. Olkowska (red.), Wydawnictwo Uczelniane Wyższej Szkoły Informatyki i Ekonomii Towarzystwa Wiedzy Powszechnej, Olsztyn.

Ejdys S., 2015, Uwarunkowania rozwoju systemu transportowego miasta Olsztyna, [w:] Liberalizm czy interwencjonizm? Ksqtaltowanie sie ladu spoteczno-gospodarczego w Europie w latach 1989-2014, R.W. Ciborowski, R.I. Dziemianowicz, A. Kargol-Wasiluk, M. Zalesko (red.), Wydawnictwo Uniwersytetu w Białymstoku, Białystok.

Grzelakowski A.S., Matczak M., Przybyłowski A., 2008, Polityka transportowa Unii Europejskiej i jej implikacje dla systemów transportowych krajów çłonkowskich, Wydawnictwo Akademii Morskiej w Gdyni, Gdynia.

Grzywacz W., Wojewódzka-Król K., Rydzkowski W., 2000, Polityka transportowa, Wydawnictwo Uniwersytetu Gdańskiego, Gdańsk.

http://eur-lex.europa.eu/legal-content/PL/TXT/?uri=CELEX\%3A52009AE1950

(data wejścia 19.05.2017).

http://hdl.handle.net/11320/2781 (data wejścia: 19.05.2017).

http://www.europarl.europa.eu/sides/getDoc.do?pubRef=-//EP//TEXT+REP

ORT+A8-2015-0319+0+DOC+XML+V0//PL (data wejścia 02.08.2017).

Krajowa Strategia Rozwoju Regionalnego 2010-2020. Regiony, miasta, obszary wiejskie, 2010, https://www.mr.gov.pl/media/3337/KSRR_13_07_2010.pdf (data wejścia: 25.05.2017).

Liberadzki B., 1998, Transport:popyt-podaż-równowaga, Wydawnictwo Wyższej Szkoły Ekonomiczno-Informatycznej w Warszawie, Warszawa.

Mendyk E., 2009, Ekonomika transportu, wydanie II zmienione i rozszerzone, Wydawnictwo Wyższej Szkoły Logistyki, Poznań.

Parysek J.J., 2001, Podstawy gospodarki lokalnej, Wydawnictwo Naukowe Uniwersytetu Adama Mickiewicza, Poznań.

Proniewski M., 2012, Rozwój regionów peryferyjnych w Unii Europejskiej. Wybrane aspekty, Wydawnictwo Uniwersytetu w Białymstoku, Białystok. 
Strategia rozwoju miasta - Olsztyn 2020, https://www.olsztyn.eu/fileadmin/katalogi _wydzialowe/ZIT/dokumenty/Strategia_Rozwoju_Miasta_Olsztyn_2020.pdf (data wejścia: 25.05.2017).

Strategia rozwoju spoleczno-gospodarczego Polski Wschodniej do 2020. Aktualizacja, 2013, https://www.mr.gov.pl/media/3372/Strategia_PW_11_07_2013_zmn.pdf (data wejścia: 21.05.2017).

Strategia rozwoju spotecżno-gospodarczego województwa warmińsko-mazurskiego do roku 2025, http://strategia2025.warmia.mazury.pl/artykuly/72/strategia-2025.html (data wejścia: 19.05.2017).

Szósty raport na temat spójności gospodarczej, spotecznej i terytorialnej. Polityka regionalna i miejska, http://ec.europa.eu/regional_policy/sources/docoffic/official/reports/cohesion6/ 6cr_pl.pdf (data wejścia: 14.05.2017).

Tomanek R., 2010, Strategie integraciji poziomej transportu, Zeszyty Naukowe Uniwersytetu Szczecińskiego nr 602, Problemy transportu i logistyki nr 12, Uniwersytet Szczeciński, Szczecin. 